\title{
Repositioning Agricultural Marketing Potential in Nigeria: An Impetus for Massive Agricultural Productivity
}

Eremiye Nehemiah*

eremiyenehemiahayobami@yahoo.com

*Department of Agricultural Economics, University of Ibadan

\begin{abstract}
Over time, the agricultural sector's contribution to the nation's Gross Domestic Product and revenue is declining exponentially; the decline may be attributed to varying problems affecting the agricultural value chain resulting in low productivity. The agricultural value chain comprises a series of activities and value addition processes required to transform raw materials into useable products to maximize the final consumers' utility. ${ }^{1}$ The agricultural value chain's marketing activities have been skewed with challenges, thus affecting agricultural productivity and agricultural sector contribution to the economy. The paper critically examines and discuss the impact of agricultural marketing to economic development, a historical review of agricultural marketing in Nigeria, challenges undermining the impact of agricultural marketing, measures to reposition agricultural marketing potential to build back better, policy recommendations to reposition the future of Nigeria's agricultural productivity. The paper aims to promote concerted efforts through knowledge dissemination to build back better through market research and facilitation and boost economic prosperity.
\end{abstract}

Keywords: Agricultural Value Chain, Agricultural Marketing, Economic Development, Productivity.

\section{Introduction}

In any economy, four basic problems arise from the central problem of scarcity of resources which include: what to produce, how to produce, for whom to produce and what provision should be made for economic growth. ${ }^{2}$ In most sector, the emphasis has always been placed on the need for what, how, and whom to produce without much consideration for what provision should be made for economic growth. The same basic economic principles lie in the agricultural sector, and much emphasis is placed on agricultural production (what to produce, how to produce) without necessary contribution for agricultural value chain management, agricultural marketing and other concepts which are skewed on ensuring provisions for agricultural productivity in a bid to improve economic growth.

From time immemorial, agriculture has proven to be a viable sector in the economic development of a nation serving as a revenue source, foreign exchange, and economic growth. The National Bureau of Statistics documented the agricultural sector contribution to the economy; from 1960 to 1969, the agricultural sector accounting for an average of 57 per cent of Nigeria's Gross Domestic Product (GDP) and generated 64.5 per cent of export earnings. ${ }^{3}$ Quite unfortunately, there was a 
decline in the trend from 1970 to late 2000s, resulting in the agricultural sector's contribution to GDP and export earnings steadily declined due to oil discovery and petroleum exploration. ${ }^{4}$

\section{Sectorial Contribution to GDP}

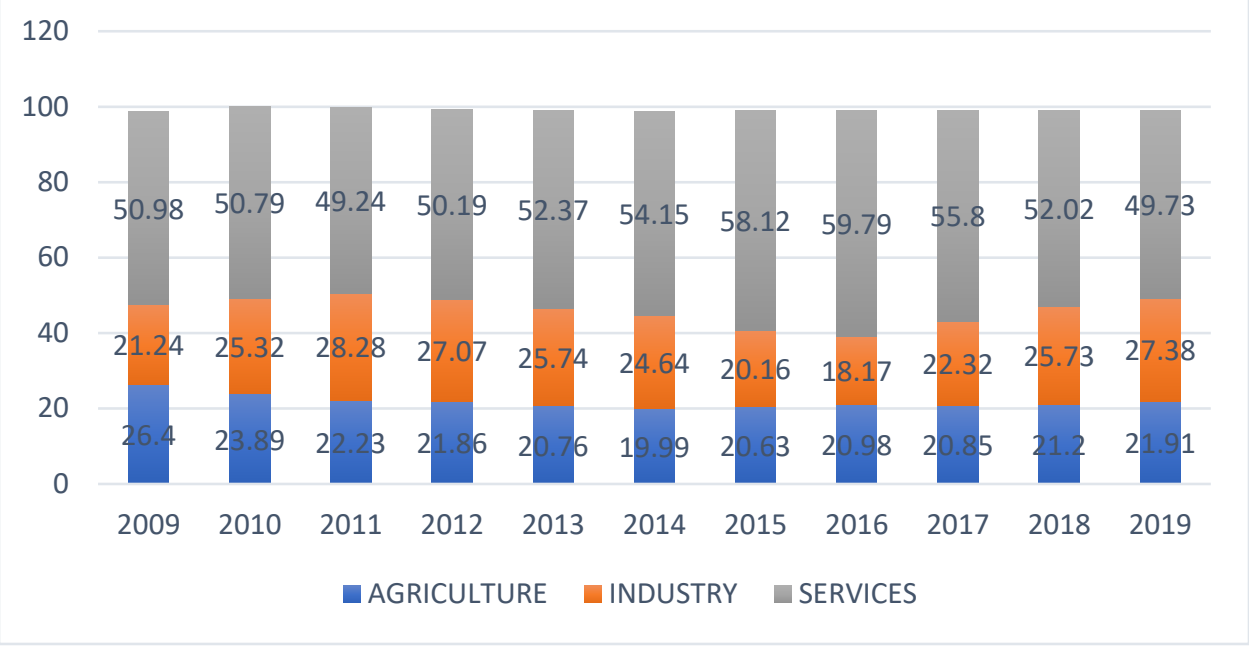

Fig. 1: Sectorial Contribution to GDP

Data Source: National Bureau of Statistics Data Visualization: Author's Conceptualization Over time, the agriculture sector has contributed an average of 24.2\% to GDP and generated 5.1\% of export earnings. More recently, the fall in crude oil prices has triggered clamour to diversify the economy into agricultural activities and solid minerals exploration and other intense industrial and manufacturing activities.

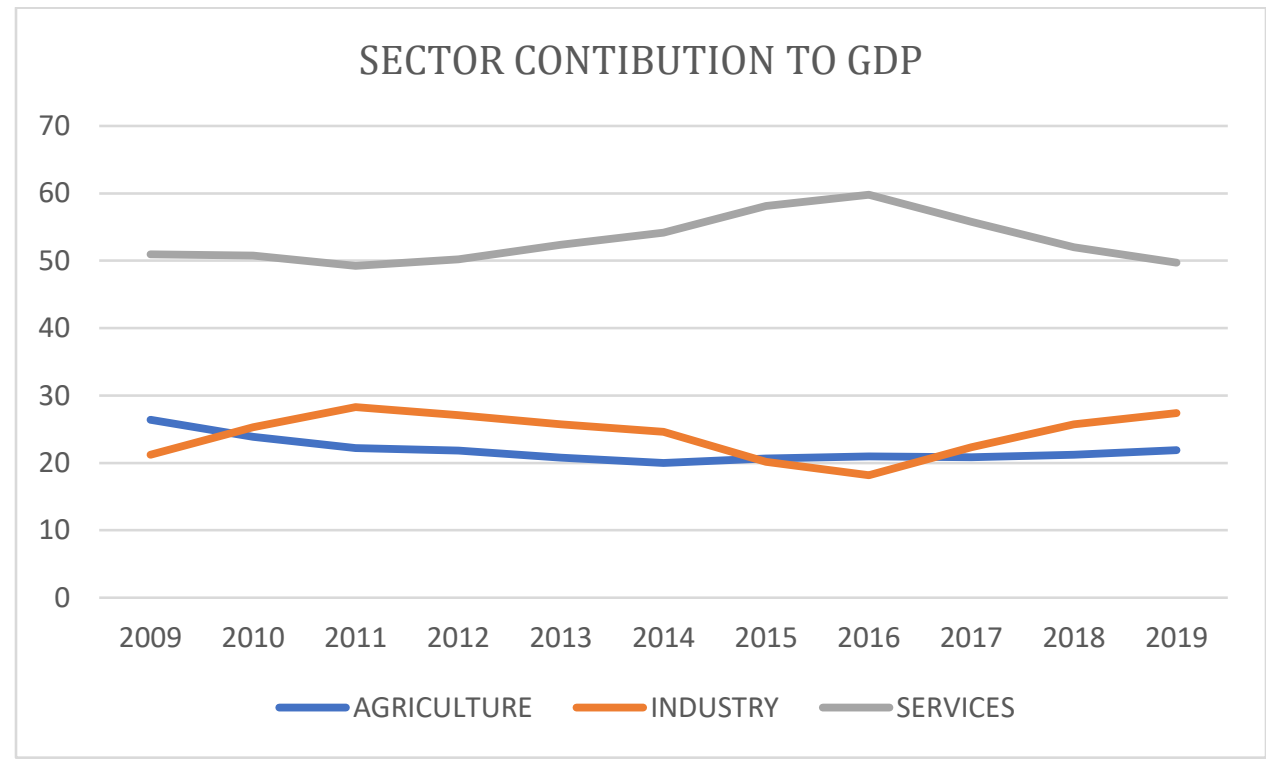

Fig. 2: Trend Analysis on Sectorial Contribution to GDP 
Data Source: National Bureau of Statistics Data Visualization: Author's Conceptualization

Despite the enormous role of the agricultural sector in the nation's economic development, it is quite disheartening and appalling that the agricultural sector productivity does not level up to par. This may be attributed to inefficient agricultural value chain system resulting in inefficient market facilitation, poor agricultural trade regulatory system, and value addition processes causing a decline in the sector's productivity.

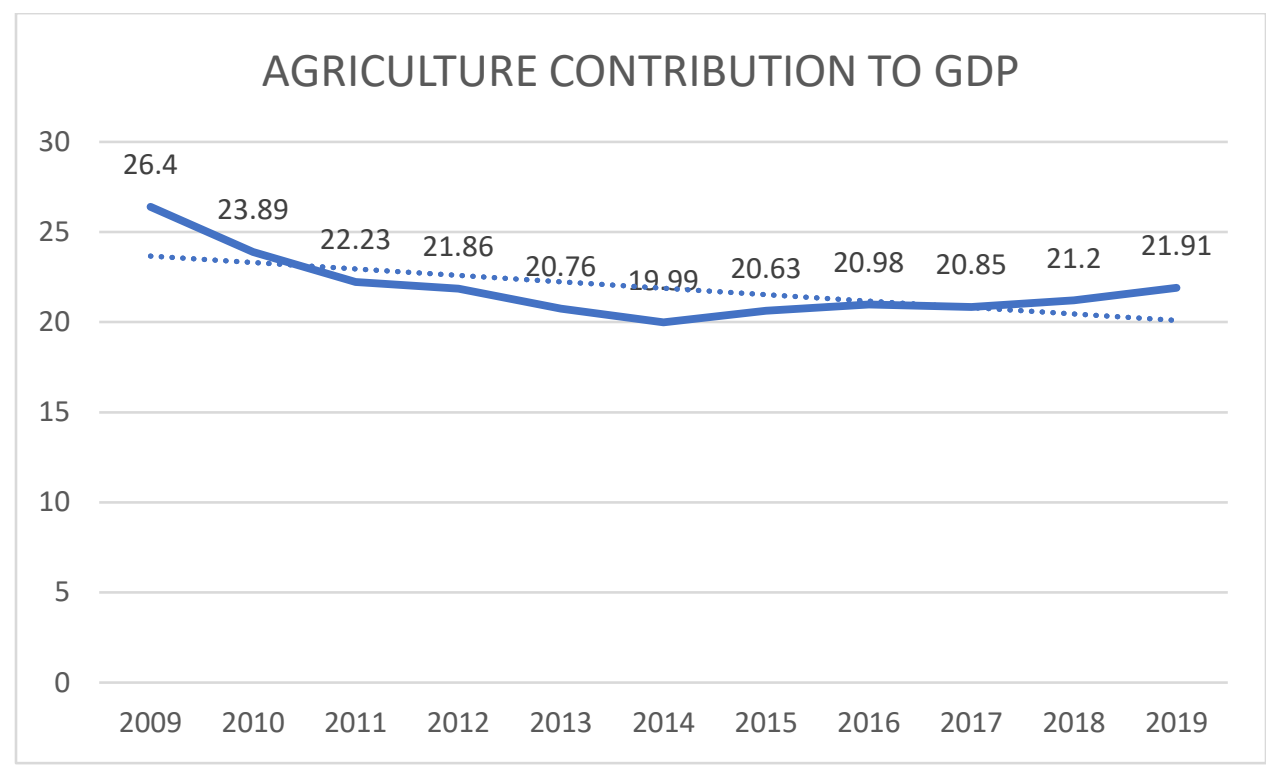

Fig. 3: Trend Analysis on Agriculture Sector Contribution to GDP

Also, with the purview of agricultural transformation leveraging on technology and Information Communication Systems and digitalized databases; it is quintessential to concert efforts to improve market facilitation and agricultural trade to promote economic development through revenue and foreign exchange generation through the agricultural sector.

It must be reiterated that the problem of low agricultural productivity in Nigeria is not due to lack of agricultural production but also inefficient value addition to the agricultural products produced, showing a deficit in value addition processes and marketing channels. There has been a paradigm shift from agricultural production to consumer demand, marketing, and the coordination of product flow from producer to consumer in developed nations. ${ }^{5}$ The value chain concept acknowledges that production must be linked to the demand and the critical role of organizing the flow from farmer to consumer opportunities, thus, positing a deficit gap for developing countries like Nigeria and a call to action to maximize the agricultural market potential through efficient value chain system. 


\section{Conceptualization on Agricultural Marketing.}

The conceptualization of agricultural marketing can be vividly illustrated from the Micro and Macro perspective.

The micro perspective to agricultural marketing is entrenched with concentration of individual participants in the marketing channel, either as a farmer, agribusiness practitioner, business firm or other actors. From the micro perspective, agricultural marketing is conceptualized as direct forward flow of goods and services to consumers in order to accomplish the producer's objectives. ${ }^{6}$ Over time, there has been misconstruing by many conceptualizing marketing as equivalent to selling or transferring the product to another person for a price but it must be noted that selling is central to the micro concept of marketing but it is only a segment of marketing and not the general concept for marketing. Marketing comprises a range of activities including packaging, storage, transportation, pricing, financing, risk-bearing and product design.

On the other hand, the macro perspective to agricultural marketing encompasses the system and process of economic activities involved in the flow of agricultural products from producers to final consumers. More so, it takes into consideration, the various governance and institutions, pricemaking mechanisms guiding the value chain systems. Also, the macro perspective to agricultural marketing captures the relationship and interactions among consumers, agribusiness firms, farmers, and even governments who determine expenditure levels and expenditure sharing as income to market participants. ${ }^{7}$

Historically, according to the National Commission on Agriculture (XII Report, 1976), the concept of agricultural marketing is described as a process which starts with a decision to produce a saleable farm commodity. It involves all the aspects of market structure or system, both functional and institutional, based on technical and economic considerations. It includes pre-and postharvest operations, assembling, grading, storage, transportation and distribution. ${ }^{8}$ More so, in the mid1900s, past governments understood the importance of agricultural marketing in ensuring increased agricultural productivity and made formal arrangements to market export crops such as cocoa, rubber, oil palm, groundnut and other essential agricultural products, thereby establishing marketing board to oversee such functions.

The marketing boards were given the charge to handle the supply chain and logistics of exports product. ${ }^{9}$ The marketing boards played crucial roles in achieving these objectives. Some of the roles played by the marketing board include:

i. Securing the most favourable arrangement for the purchase of products and arrange for the export of cash crops.

ii. Maintaining legally prescribed grades and standards of quality of export produce.

iii. Allocating funds to the appropriate authorities through grants, loans, investments and endowments purpose of economic development and research. 
iv. Supplying produce to local processors for processing in their plants, and

v. Stabilizing producer prices by fixing legal minimum buying prices at a time and minimizes price fluctuations within and between seasons among many other roles.

The marketing boards performed great functions in exporting cash crops to European countries resulting in a high export share and revenue generation. However, the marketing boards were impeded by various challenges such as standardization and grading of export crops in the international market, which had a significant impediment to Nigeria's agricultural productivity, resulting in declines in revenue and foreign exchange.

In our current agricultural situation, achieving equilibrium in inefficient agricultural marketing through efficient grading and standardization has been a herculean task. Thus, the need for concerted efforts towards improving the agricultural value chain system, governance and institutions processes to improve the agricultural marketing potential and agricultural productivity in Nigeria.

\section{ROLES OF AGRICULTURAL MARKETING}

The role of agricultural marketing in ensuring massive agricultural productivity cannot but be overemphasized; this results from efficient marketing functionality in ensuring agricultural products reach the final consumers and satisfy their utility. More so, agricultural marketing ensures that agricultural products' quality is maintained through efficient standardization and grading to ensure general acceptability, especially in international markets.

Over time, agricultural marketing plays a vital role in stimulating production and consumption and contributes immensely to economic development. Such roles performed by agricultural marketing include:

1. Optimization of Resource Use and Output Management: Efficient agricultural marketing system is quintessential to optimizing resource use and output management. Also, contributing to an increase in marketable surplus by scaling down losses arising from inefficient processing, storage, and transportation.

2. Increase in Farm Income: Higher levels of income for farmers could be generated through an efficient marketing system. This is quite possible because it could create a system to reduce middlemen's exploitative activities, restricting the cost of marketing services and transactions involved in the marketing of farm products. This, in a way, could guarantee the farmers' better prices for their agricultural products, inducing them to invest their surpluses in the other agricultural inputs in a bid to promote productivity, and production may increase. Overall, this will result in an increased market surplus and farm income for producers and agribusiness participants.

3. Widening of Markets: Efficient agricultural system could spur the widening of markets for agricultural products beyond production and producing country shores. This could be 
possible due to efficient standardization and grading, ensuring that quality agricultural products are produced. This will increase the demand of such products continuously, thereby guaranteeing a higher income to the producer.

4. Growth of Agro-based Industries: An improved agricultural marketing system could boost the growth of agro-based industries. Thereby stimulating the overall economic development of the country. In the words of Arthur Lewis, 'If agriculture remains stagnant, industries will not grow.' The agro-based industries' improvement through efficient agricultural marketing systems will ensure an adequate supply of raw materials for industries to boost production.

5. Price Signals Transmission: Transmission of price signals is ensured through an efficient agricultural marketing system. This is quite possible as farmers can plan their production per the economy's demand and determine market prices based on varying factors.

6. Adoption and Spread of New Technology: Marketing system helps the farmers adopt new scientific, technical knowledge and innovation. The new technology requires higher investment, and farmers would invest if they are assured of market clearance at a remunerative price.

\section{Problems confronting Agricultural Marketing that affects massive Agricultural Productivity}

Agricultural marketing in Nigeria is posed with myriads of problems, which contributed to the decline in agricultural productivity. This is so because agricultural marketing plays a crucial role in agricultural transformation, but agricultural marketing has not been given considerable attention compared to agricultural production over the years.

The essence of agricultural productivity is not in massive agricultural production instead in the products being translated from farm to fork, farm to industries and other usefulness needed to generate revenue and foreign exchange for the economy, which can only be achieved through efficient agricultural marketing mechanism.

Few among the limitations of agricultural marketing in Nigeria, resulting in low agricultural productivity include:

Inadequate infrastructural facilities: In any economy, efficient infrastructural facilities are quintessential in improving the investment climate. ${ }^{10}$ The same logic applies to the agricultural sector, inadequate infrastructural facilities have resulted in problems in the agricultural value chain system, logistic concerns which result in the poor agricultural marketing mechanism. Infrastructural facility deficits such as inadequate road network and poor telecommunication services are impediments to agricultural productivity. A study conducted in Kwara State found that the high cost of transportation, bad roads and long distances from the farm to the market negatively impact agricultural produce marketing. ${ }^{11}$ 
Inefficient on-farm storage facilities: Agricultural production is skewed with many challenges such as postharvest losses and pest invasion. However, oftentimes these challenges can be overcome through the efficient agricultural marketing system. Reports show that most agricultural products (often perishable) go from farm to dustbin due to inefficient storage facilities and lack of value addition processes of agricultural products. ${ }^{12}$ This has resulted in a skyrocketing agricultural produce wastage and loss of revenue.

Problems of standardization and grading: Agricultural productivity in Nigeria has been greatly impeded with standardization and grading issues. To ensure massive agricultural productivity and stimulate economic growth, there is a need to ensure quality standards and grade of agricultural products to meet up with international markets and generate export earnings from such products. Due to standardization and grading problems, our agricultural products do not meet up with the international market's standard requirements, which invariably affects our productivity since such agricultural products will not be highly demanded, causing a reduction in foreign exchange and sources of revenue. Statistical reports showed that between 2010 and 2014, Nigeria's cocoa output declined by 37.9 per cent to 248,000 tons due to standardization and grading, causing a shortfall in revenue generation and agricultural contribution to the nation's Gross Domestic Product. ${ }^{13}$

Insufficient market intelligence, marketing communication and research: Agricultural marketing has been impeded due to insufficient market intelligence, most especially in the area of research and development. Most agricultural products are devoid of value addition processes resulting in insufficient utility standard and constrained demand. For instance, reports show that 80 percent of Nigeria's cocoa beans are exported to European countries who then process the cocoa into various products such as chocolates, beverages, cocoa pellets, and other useable forms to provide maximum utility for the final consumers. Interestingly, cocoa's value-added products are then imported to Nigeria, which we purchased at exorbitant prices. ${ }^{14}$ This is as a result of insufficient market intelligence in ensuring value-added processes are carried out on our agricultural products and not being sold in their raw state instead of processed into other useable forms to ensure utility, showing a gap in the marketing communication, research and development resulting in limitation in agricultural productivity.

Ineffective policy formulation and implementation: One of the significant problems in the agricultural sector is inefficient formulation and policies implementation. Policies formulated by policymakers regarding agricultural marketing are most times poorly implemented or not implemented at all. The existing policies are not supportive enough for agricultural marketing transformation such as the land use act, tariffs on imports of agro-inputs, and machinery.

\section{Policy Recommendations: Repositioning Agricultural Marketing in Nigeria}

Agricultural value chain development and improvement of agricultural marketing hold great potential in boosting agricultural productivity of the nation. Agriculture has played a vital role in 
stimulating economic development in the past; we could hinge on past efforts and technological improvements to develop the agricultural value chain and other subsectors in agriculture.

When this is achieved, there would not be only massive agricultural productivity but adequate food all-round the year, sufficient raw materials for industries, actual agricultural products for exports to international markets, the satisfaction of utility of consumers and income for both farmers and operators in the agricultural value chain and more so, foreign exchange earnings for our nation

All these benefits cannot be achieved in our agricultural marketing system; thus, the need for implementation of the following policy recommendations:

Provision of efficient infrastructural facilities: Infrastructural facilities such as good feeder roads, storage, processing and packaging facilities are significant in ensuring improved agricultural marketing. Efficient infrastructural development will serve as an incentive for investment in the agricultural value chain and other agricultural subsectors with the purview of spurring agricultural productivity. More so, one of the significant impacts of infrastructural development in spurring agricultural productivity was witnessed in 2012, when USAID funded the Nigeria Expanded Trade and Transport (NEXTT) project to advance trade efficiency along the Lagos-Kano-Jibiya (LAKAJI) corridor. By 2015, the project facilitated a 25 per cent reduction in time for importing goods and 5 per cent decrease in time for exporting goods through Lagos to Jibiya Border. Also, a 35 per cent decrease in cost-to-import and 21 per cent reduction in cost-to-export was recorded for goods passing through the corridor. ${ }^{15}$ With more infrastructural development, agricultural trade efficiency and productivity will be greatly improved.

Provision of extension officers with the technical know-how on agricultural marketing and Value Chain Development: To reposition agricultural marketing, extension workers with the technical know-how on agricultural marketing and agricultural value chain processes should be deployed to rural areas to orientate and train farmers on efficient agricultural marketing and value chain but also help to ensure increased productivity from the farmers through the sensitization on new technologies, improved varieties among others.

Improvement in standardization and grading system: There is a need for an improvement in our standardization and grading system to produce quality and standard agricultural products that can satisfy consumers' needs and meet the requirements of the international market. This will result in high demand for our agricultural products and serve as an impetus in ensuring massive agricultural productivity to meet up with global demand.

Encouragement of Agribusiness Clusters and Cooperative Societies: Cooperative societies play a significant role in ensuring massive agricultural productivity. This is due to farmers, and agribusiness owners coming together to ensure that agricultural products are efficiently marketed. Thus, increasing agricultural productivity as farmers in cooperative societies will gather all their products to market them in bulk and ensure their profitability and increase agricultural productivity. 
Improvement in Market Intelligence, most significantly, Market Research and Communication: Market intelligence plays a critical role in reducing risk level in decision making. Through market intelligence, the agribusiness practitioner and farmers can decipher customer needs and quality requirement. Marketing research and development will be quintessential in determining what products are right for the domestic and international market, appropriate distribution channels, value chain development and agricultural product quality and standard. ${ }^{16}$

Resuscitation and Reformation of Agricultural Marketing Boards: Marketing boards played a critical role in the procuring, grading; marketing arrangements and export of cash crops. The marketing board was responsible for developing the Nigerian agricultural export industry, translating to a significant contribution to economic development and GDP growth. Marketing board reformation should be encouraged to ensure that the goals of the agricultural marketing boards are sustained. After the reformation, the agriculture marketing boards will carry out three functions: regulation, market facilitation and change agent. As a facilitator, the marketing boards will function in credit, market intelligence and risk management capacity. ${ }^{17}$ More so, marketing boards' role to function efficiently marketing is most often framed by policymakers in modifying the market structure, and all this will help ensure massive agricultural productivity.

Effective Policy Formulation and Implementation: Policies that will improve agricultural marketing should be formulated and efficiently implemented. Policies such as market liberalization which will encourage Public Private Partnership can be formulated to encourage both public and private sectors' involvement in agricultural marketing and the value chain development. This will, in a long way, boost agricultural productivity.

\section{CONCLUSION}

Agricultural Value chain development and efficient marketing is key to massive agricultural productivity. As such, efforts should be concerted towards setting up fundamental structures, governance and institution with the purview of transforming the agricultural value chain and marketing system. The agriculture sector holds great potential in boosting economic development, however, policy recommendations as cited in the article among other recommendations should be employed in translating agricultural production into productivity channels for revenue and foreign exchange generation.

\section{REFERENCES}

1. Food and Agriculture Organization (2010), Agricultural Value Chain Development: Threat or Opportunity for Women's Employment? Gender and Rural Employment Policy Brief \#4

2. Young R. (1987), Basic Economic Problems. In: Work Out Economics GCSE. Macmillan Work Out Series. Palgrave, London. https://doi.org/10.1007/978-1-349-09348-9_2

3. National Bureau of Statistics (2012). Retrieved on October $10^{\text {th }}, 2020$ from http://www.nigerianstat.gov.ng/sectorstat/sectors/Agriculture 
4. National Bureau of Statistics (2012)

5. Jeff Okorafor (2014), Agricultural Value Chain Benefit. Accessed online from https://opinionnigeria.com/2823/. Retrieved on November $23^{\text {rd }}, 2020$.

6. Olukosi, J.O., S.U. Isitor and M. O. Ode (2012) Introduction to Agricultural Marketing: Principles and Applications. Living Books Series, GU Publications, Abuja FCT, Nigeria

7. Ode, M.O, B.O. Duru-Nnebue and C.M. Mathen (2007) Fundamentals of Marketing: Principle and Applications. Newcomb Communications, Nagwanatse House, Kaduna.

8. National Commission on Agriculture (XII Report, 1976): Agricultural Marketing and Perspectives. Accessed online from http://www.eagri.org/eagri50/AECO242/lec01.html. Retrieved on November $21^{\text {st }}, 2020$.

9. Omorogiuwa O., Zivkovic J., Ademoh F. (2014), The Role of Agriculture in the Economic Development of Nigeria. European Scientific Journal February 2014 edition vol.10, No.4 ISSN: 1857 - 7881 (Print) e - ISSN 1857- 7431

10. Muogbo (2015), Improving the Investment Climate in Nigeria: Issues and Policy Options

11. Usman B.A, Adefila J.O, Musa I.J (2013): Impact of Rural Road Transport on Agricultural Production in Kwara State, Nigeria. Nigerian Journal of Agriculture, Food and Environment. 9(2):20-25

12. Punch Newspaper (2016), From Farm to Dustbin: Plight of Nigerian Farmers battling PostHarvest Losses. Accessed on www.punchng.com/from-farm-to-dustbin/ Retrieved on December $3^{\text {rd }}, 2020$.

13. National Bureau of Statistics (2015)

14. Proshare Ecosystem: Reviving the Cocoa Industry in Nigeria. Accessed on www.proshareng.com/news/Agriculture/Reviving-the-Cocoa-Industry-in-Nigeria/37675. Retrieved on December $4^{\text {th }}, 2020$.

15. Gidanmana U.P (2020): Transforming Nigeria's Agricultural Value Chain. World Journal of Innovative Research (WJIR) https://doi.org/10.31871/WJIR.9.3.23

16. Food and Agriculture Organization (2014), Agriculture and Food Marketing. Accessed on http://www.fao.org/3/w3240e/W3240E01.htm. Retrieved November 25 $5^{\text {th }}, 2020$.

17. Cited as 9 